\title{
Feminists' Culture and Ethics at Work—A Critical Analysis
}

\author{
Dr. Jayshree Singh \\ Bhupal Nobles’ Post Graduate College, Udaipur (Rajasthan), India
}

\begin{abstract}
The male writers' intuitive gift and superb insight describe feminine characters, feminine nature, femaleness, and femininity. In the 19th century, the study of the character logical portrait and cultural traits associated with femininity enunciated feminists' discourse to justify vindication of rights as regards women's cultural anxiety, political identification, and aesthetic experimentation. Similarly, the women writers' imaginative powers characterize women's emotions either reflecting shrinking subjectivity or elaborating notion of voluntary subjectivity as regards their experiences and existence, their passions and sensations, and their self and life. The 20th century women's writings raised inquiry against presentation of gendered self, performance of gender, gender discontent as regards with their sex and gender, which are assigned at birth as well as also for the alignment of biological sex, sexuality, gender identity, and gender roles. In this paper, the study of the four selected novels such as The Scarlet Letter, Tess of the D'Urbervilles, Emma, Surfacing, and Inner Line shows how circumstances, strata of time, and externalities of others objectify woman and her domestic space; how a woman perceives her deprivation as regards her own image which seems nobody to herself due to the sense of low perception; in what way sexual difference and gender-specific practices and ideology enforce woman to chide herself in the given environment and surroundings of legal codifications, moral prescriptions, and medical prognostications. The analyses of the novels draw how woman's experience as living subject in the vital dimension of human existence and utopian image of human fellowship is potentially undone by way of sexual exploitation, dismemberment, and embodiment. What kind of vulnerable moments force woman to withdraw from her body and from her essence is the center of concern in this paper? While discussing the feminists' culture and ethics in their works, the focus is on the essentialized notion of gender-specific discrimination as well as on the frustrating double-consciousness that characterizes the cultural position of the other.
\end{abstract}

Keywords: feminists' discourse, femininity, gender-specific practices and ideologies, ethics, double consciousness, cultural position and dismemberment

\section{Introduction}

The binary oppositions have always prevailed between males' rule and females' concerns. Men in their most extremes become suppressive patriarch, misogynist, masochistic, chauvinistic, and sexually dominated and culturally powerful gender in the society, while there is also opposite side of men that is associated with reason, objectivity and logic. Similarly, women writers develop their perceptual perspective for women in their writings as repressive, weak, insecure, sensitive, emotionally relational and fluid; on the contrary, men writers have imagined the image of women as docile, subservient, strong, determined, and compassionate. However, it is not completely acceptable to complete the image of the women, by women, and for women. In view of the

Dr. Jayshree Singh, Associate Professor, HOD English, Bhupal Nobles’ Post Graduate College, (MLSUniversity) Udaipur. 
20th century feminist writers' perspectives, through women characters' social intelligence and general knowingness have been voiced in the text as per geographical space, social order, historical constraints, cultural customs, and hierarchical forces prevalent during the authors' time. According to these Western women novelists, the self-creation of femininity enables women characters to become strong, independent, and emancipated and their determined sexuality is centered on the domains of women's lives and minds, interconnectedness and effectual rationality (Rose, 2001) i.e., women's identity and existence is not to be dealt epistemologically political or as politics, but as holism and a harmonious relationship with nature and making combinations as wholes in human life (Woolf, 1938). The state of feminists' social attitude and attributes in the study of the selected novels of Margaret Atwood, Jane Austen, Nathaniel Hawthorne, and Thomas Hardy is developed per se the contemporary social milieu, norms, and biasedness. Indeed these novels essentialised women as other or as fair sex, not as gender in equity. The analyses attempt to disclose bold and strong women Emma and a talented Canadian woman artist, who pose castrating threats to men and are canonized as "madwomen in the attic" (Ryan, 1999, p. 104), because they have tried to subvert their professional, private, and social life. The study has taken up two other 19th century male writers to understand the male perspective, sensitivity and logic of depicting femininity and femaleness both in context of gaze and gain for social and sexual role which is male-driven.

\section{Analyses of the Selected Novels}

\section{The Scarlet Letter}

Nathaniel Hawthorne's Scarlet Letter (written in 1837 and published in 1850) draws historiography and mythopoeia, power, passion, and betrayal in the book. The author himself belongs to the 19th century American society who attempts to explore American society in its Puritan past of New England during 17th century. The novel traces individual's predicament which is portrayed in three characters of the novel differently: (1) desolation on account of societal hostility; (2) guilt-conscience and spiritual despair due to concealment of the truth; (3) sense of vengeance and immorality deep inside the heart. These are Hester Prynne, Arthur Dimmesdale, and Roger Chillingworth respectively. The lead character Hester is the sufferer who is accused of a sin without any sound proof of adultery, but the way Hester's journey as mother of illegitimate child documented, illustrates the effect of the sin in the form of alienation and outcaste. The silence and religious outlook of Arthur Dimmesdale, the church priest, not only increases the pains and perils of Hester, but all the more degenerate the passion of revenge in the heart of Hester's truant husband Roger Chillingworth. It shows the bigotry of the male-dominated Puritan society, religious conviction, and double standards of the Church, and the anarchic tendencies of human passions. All these salient factors of masculine gaze and gain condemns woman Hester Prynne as sinner of adultery and she has to face stigma and guilt of being illicit lifelong by wearing the letter " $\mathrm{A}$ " on her breast in the crowd surrounding Endicott of the region New England.

Hawthorne's interest in this event autobiographically relates to an event that happened in Salem (Massachussets) in 1688, in which Hester Crawford was persecuted to be whipped publicly by Salem Law Court that was completely controlled by Church and its Puritan conventions. She was charged of being in intimate

relations with John Wadg, and one of the Nathaniel's ancestors, William Hawthorne passed the sentence. In actuality, the book, according to D. H. Lawrence, constitutes Hawthorne's deep-seated fear of the female, his misogyny—notwithstanding Hawthorne's famed love for his wife; thus Hyster Prynne becomes (in D. H. Lawrence's scheme) an omnivorous, prehensile woman that devours and corrupts the malehood, the spiritual 
integrity of Arthur Dimmesdale through dissimulation of her true predatory instincts (Lawrence, 1924).

This novel with its first declaration of American Literary Independence basically paved the element of modernism in the latter half of the 19th century. It re-mapped the roles of gender and sexuality in the historical accounts. It set the discourse on the intricacies of love and marriage, challenged bourgeois conventions of "character" and attempted to enforce a paradigm to fashion and discover "self”. It probed American society and culture that "consistently and obsessively gendered as feminine by a male-dominated high culture" (Lyon, 2005/2008, p. 221). It emphatically argued the problem of sexual difference that arrayed across the legal and social reforms, and proposed radical individualism with "the position insisting on the equality of men and women in the eyes of law and within the fundamental principles of the republic" and as "the 'disabilities' accruing to the female sex were man-made and therefore remedial through egalitarian legal and social reforms" (Kalaidjian, 2005/2008, p. 222).

Symbolically, the novelist disposes ethical, “convenient taxonomy of romance” (Schiek, 2009, p. 40) and exposes sexual practices and desires that relatively denote heterosexual paradigm "within which the nexus of female/femininity/woman necessarily derives critical significance in relation to male/masculinity/man" (Lyon, 2005/2008, p. 227). The novel at the same time imposes allegorically "the part moral and simplified character" (Fiedelson, 1953), which is ironically in contrast to human frailty and sorrow that enchains a woman's life in social constructions and sexual exploitation or when males' dominated, privileged sexual implications and desire impinge women's personal autonomy and idealized domestic space.

\section{Tess of the Dubervilles}

Thomas Hardy, the Victorian age British novelist of nineteenth century, got his novel Tess of the Dubervilles published in 1891. He portrays the heroine of the novel Tess as an appellation of a pure woman whose flesh and blood exude animalism and seduction to enchant males' sexual desire and lust, just as Alec Duberville exploits her as a virgin girl; while Angel Clare marries her in pursuance of her sexuality as an embodiment of male's privilege and preference for chastity. But alike, Hester Prynne of the novel Scarlet Letter, her immoral act is perceived in context of various degrees of darkness in the surrounding characters. These characters represent mobile, displaced, economically ailing English countryside middle class that symbolizes an index of aspiration for whom the sexual desire was a makeshift between a vision of fulfillment and a frustrating reality, in which women being margin, secondary and other become victim both of redemptive theology and skeptical, conventional views regarding womanhood and her equanimity with nature.

With Angel Clare we are back to intellect, with all its limitations. An amazing proof of this is his practice of putting before Tess merciless arguments from the repertoire of skepticism, arguments which not only destroys Tess's simple faith, but ricochet off to bring down Alec d’Uberville and himself. (Duffin, 1916, p. 50)

In relation to women, particularly Tess, he follows the narrow Victorian double standard—one principle for men, the other for women. In his case, when he narrates his adultery with a woman, he wants Tess to forgive him, but he does not forgive her for the same type of fault, even though he knows she has been a victim of social and economic conditions. He is squeamish about Tess's chastity. He flatly tells her that he believes in a spotless character of a girl and that he hates any lapse from the path of virtue in matters of chastity. He admits that Tess is more sinned against than sinning, but he is not ready to forgive her. He says very callously:

I cannot help associating your decline as family with this other fact-of your want of firmness. Decrepit families imply decrepit wills, decrepit conduct. Heaven, why did you give me a handle for despising you more by informing me of 
your descent! Here was I thinking you a new-sprung child of nature; there were you, the belated seedling of an effete aristocracy. (Hardy, 2002, p. 45)

Through this novel, Hardy brings out how capitalist trend of ambition and environment exploration in disguise promotes youth of the modern civilization to break norms of moral life. Woman or nature becomes the gaze of exploitation and masculine gaze disembodies the spirit of woman from her own self-consciousness for her body. Her body is neglected to be taken care of. Culture and conventions as regards naturalness of sexuality appear to be repressive and challenging, but at the same time the "natural" in context of women's bodies is realized in brutal indifference and tragically as material reality (Eagleton, 2005, p. 192). It is apt to express that novel itself oscillates between treating Tess as an object of erotic desire or "scientific" investigation and feeling genuine compassion for her. If she is a woman in her own right, she is also an object for readers' consumption (Hardy, 2002, p. 194). Even Penny Boumelha argues in this concern in her book Thomas Hardy and Women, it may well be that through the figures of Angel and Alec the story puts into question its own objectifying of its heroine, just as it may also call into question its own sublimated desire for her (pp. 178-179).

Besides the theme of incestuous marriage, Hardy also focuses on maladjustments in social life due to marriage in one of his novels The Mayor of Casterbridge. Hardy expresses his view in one of his novel: "The ruin of good men by bad wives, and more particularly, the frustrating of many a promising youth's high aims and hopes and extinction of his energies, by an early imprudent marriage” (Hardy, 2002). Thomas Hardy faced condemnation on this issue, as he blasted the very foundation of morality and orthodoxy. According to him, marriage can be broken at will; it is not a sacred bond. It is good to seek dissolution of marriage bonds, if marriage has failed to make the partners happy. Though Hardy, on account of protests and propaganda against him, gave up writing novel, but his views were upheld by the modern divorce laws (Butler, p. 299).

\section{Emma}

Emma by Jane Austen was published in December 1815. The novel's main heroine Emma, despite all her faults, shortcomings, and errors of judgment, is liked by the readers. Emma in the novel is depicted as strong-headed, caring and cultivates an image of female difference and experience. She constructs around her an aura of contextualization of knowledge, becomes a necessary human agency, creates a predominant causality in relationships and floats inter-subjectivity and interactive process, and even hunts multi-formed regularities or diversity to help other women in order to search better counterparts as according to their disposition and countenance. She stresses the values of empathy; nurturance and that "choices" are really demands of situations (Grimshaw, 1986). The book Emma professes its concerns through the characters that learn by experience and mistakes. For example, Mr. Knightley must learn to be teased by his wife. Emma learns to know herself and how delightful it becomes knowing herself. It helps the characters to be morally serious and discriminate the constraints and forces from the contemporary demands and situations. Jane Austen artistically and creatively builds up Emma's supreme self-confidence but at the same time she differentiates it with her serene delusions in order to convey the readers the message from the novel that women too could be illusory in her perception if she is snobbish, domineering, rash, and selfish. The author characterizes her to be able to win the situations with her radical transforming steps. Simultaneously the author evolves Emma's personality out of complexities of reality in order to show that an officious and self-confident girl does have to cross self-deceptive illusions, misleading appearances, moral preoccupations, social surroundings, and unpleasant possibilities for finding some mode of existence. In order to have realization of true self-awareness and to be more self-resolved, 
Emma's critical attitude helps her to be expressive and knowledgeable for having better human relationships in the society. In context of characterization of Emma and other female characters in Jane Austen's novel Emma, it is apt to relate Mary Wollstonecraft who thinks that women need to analyze their uncultivated understandings, to follow noble pursuits, to allow their constitution to retain its natural strength, to condescend to use art for not highlighting little vanities and excite tenderness or to gratify the arrogant power of man, but to use art to assert their claim to pursue reasonable pleasures and render themselves conspicuous by practicing the virtues which dignify mankind.

This book is relevant in understanding British feminism and social ethics in context of Indian settings because the question of woman's writing as per se feminist thought is to break the silence and the writing connects the space between the private (personal feelings) and the public spheres (social surroundings or state of life). Rajeshwari Sunder Rajan alleges that the writings that inscribed space from the gendered perspective and concept exhibit within the mind of the novelists; it is the polarized categories of "home" and "world". She further adds that some sort of division of private and public spheres seems to have always and universally accompanied the construction of genders or as a division between the spaces of "aham" (inner) and "puram" (outer) corresponding to the polarity of love relationships as in European eighteenth century between the bourgeois society and the elite class or in reproduction (child-bearing) and productions as under capitalist social systems, so social values as regards feminist consciousness do play significance in forming excessive or transgressing image of new woman in any society.

\section{Surfacing}

Margaret Atwood's Surfacing articulates through the narrator, who is a talented woman protagonist the issues of gender, voluntary notion of subjectivity, madness, nationality, ecology, and narrative power, Eventually, it debates in retrospect the question of Canadian's identity as parallel to the question of a woman's quest for freedom and autonomy and both questions are resolved in perceiving the surroundings in a new way and as a harmonious natural order. In this novel gender relations are destabilized from a feminist perception and vision because the protagonist attempts to valorize the woman's effort to gain a self-reflexive knowledge of the power-relations that defines the protagonist's identity, an identity which will in turn be rejected or shed like a dead skin (Lane, 2006, p. 71). The novel brings thematic shift in two predominant parallel problems. Firstly, Surfacing concentrates on the theme "the Canada—as the collective victim" and discusses the threat of Americanism to Canada's national identity. Secondly, Surfacing allegorically deals with raising people's consciousness against getting alienated from their moorings, their culture, their ideal Canadian pasts, their people, and their language that was in a state of creolization and hybridization due to hegemonic influence and technological advancements. Within these global and pluralistic situations are hidden the symbolic powers of patriarchal codes in context of the issue of a married woman, who searches her identity in the wilderness of being treated as material or spatiotemporal thing. The narrator undermines her status as a married woman and reveals her marital status to be performance or a lie because she undergoes through the voluntary notion of subjectivity as regards aborting her child. She felt that her body becomes merely a meeting point of physical and psychical and it becomes a victim of causal relations within itself and in its environment. Her child in the womb (another living body) dies not because of causal relations but because of motivational connections between "corporeality and inter-subjectivity" (Zahavi, 2005) that puts human situation and existence in controversy in terms of subjectivity, freedom, and society. To illustrate the notion of an opposition in the words 
of Beauvoir: There will always be certain differences between men and women; her eroticism, and therefore her sexual world, have a singular form of their own and therefore cannot fail to engender a singular sensuality, a singular sensitivity. Her relations to her body, to that of the male, to the child, will never be identical with those the male bears to his own body, to the feminine body, and to the child. It is because of this sexual difference and dependence in her marital status, the narrator in the novel Surfacing is unable to distinguish at first between embodiment and existence, between for-itself and in-itself, therefore her short married life could not create a rich and convincing bodily subject and she undermines her marital status in the novel. She surfaces through patriarchal language with her own definitions of being a woman and a victim; later through her search of missing father, she defines her own body's spatiality, motility, sexuality, and expressivity (Card, 2003, p. 74). She finds an appropriate form for her own story of survival and relations within a quest narrative. She shifts from a position of alienation and victimhood to a new sense of the vital relationship between herself as human and the land she inhabits, though it also signals a further stage which she has to face in coming to terms with human beings in the modern world. Margaret Atwood tries to rehabilitate one's self in the "home" and the "world". The narrator discovers her symbolic journey of life through memory of immigration to Toronto from Quebec and then returning to Quebec. Following the empty state of her marriage and search for the father, confused values of her childhood, her victimized adulthood; the narrator goes through nostalgia, neurosis, and self alienation at first, then she later overcomes through her explorations and direction-finding maps to locations and meanings. Like an escape artist, she plunges into the purifying element, the unknown and the unconscious. Thus Margaret Atwood interrogates the incomprehension, confusion and ambivalence of the woman who is caught in progressive insanities i.e., a new way of conceiving not only idea but also events and time that is disturbing and powerful, at the same time providing alternative but isolated perspective that causes suffering on heroine's peaceful existence and that adds unconscious dimension of herself especially when it comes to women's power to control their bodies i.e., abortion or dead marriage.

\section{Inner Line}

The Zubaan book of stories by Indian women canonizes the women's dependency, deprivation, and desolation in the Third World Cultural Studies. The Indian women writers in the short stories convey that oppressive structures, oppressive traditions, and oppressive patriarchy which marginalise women's position and they develop low self-perception in the social and cultural contexts and in biospheric context. The book purports women's psychology in relation to the representation of their image in myths/epics/religion. It brings forth the powerful emotive forces that negotiate women, work, health, and her sexual orientation in cultural and economic contexts. The focus of the book is on women's struggle for private space, her consciousness for autonomy and self-determination which is ruthlessly suppressed by the threats of predatory males. The issues of the social-cultural world that the women construct around her in their narratives contextualise subjective experiences and textual meaning as regards to female body and choices. The book questions the utopian vision of society in which women's choice, integrity, dignity, security, equality, and respect are the imagined choice of Indian men in isolation. The story "Incantations" by Anjana Appachana metaphorically presents the narrator's prayer for hope and for compensating her guilt; the author's resistance against the deteriorated sanctity of shlokas chanted at the time of wedding ceremony and the self-denial of narrator's mother into fanatic religious praying engulfs her into delusion and detachment; and these all incantations could not save the victimisation and violation of the narrator's sister. The story "Wet Nurse" by Mahasweta Devi portrays a 
woman's enchantment towards her being feminine and to be the centre of masculine gaze-as an object or the other sex or to be the iconic example of motherhood/womanhood, but in the end, when her old age fades her sensuality and motherhood, she faces desolation. This predicament dislocates her identity and position both in social and cultural context. The story "A Kitchen in the Corner of the House" by Ambai reflects upon the self-effacing woman's life whose respect forms through her attributes of nurture, care, and compassion towards the members of the family and society, but she forgets when she will have no beauty to wear jewellery, no authority to carry on kitchen affairs or no strength to take the load of members of family, then only her contribution to world through her inner space would be counted, of which she is mostly deprived of or unknown to. To understand the Foucault's view of resistance of the body, it is to visualize the body in terms of its materiality. Taylor writes that "women shaping their bodies in service of patriarchal normalizing power indicate their female body in docility and obedience to cultural demands" (p. 95).

\section{Feminist Writers' Culture and Ethics}

The feminist readers and writers such as French feminist Luce Irigaray exposes the disrupting power of male identity in social institutions and their excessive practice of material outlook by males over women's bodies. The Anglo-American feminists engaged in male discourse in order to establish the fact that male-dominance is the symbol of canonizing the male's authenticity over all spheres of women's life. Many feminist critics believe that women potentials and strengths are represented as calumny and contempt by men. Many historical feminists such as Charlotte Perkins Gilman, Kate Chopkin, Elizabeth Bishop, Robert Lowell etc., legitimize the canons of feminist social ethics in the feminist discourse.

In feminist theory "female" word depicts the purely biological aspect of sexual difference and the word "feminine" is the term that idolizes the social construction of women. The word "woman" is constructed socially in binary of "man", whereas ideologically the word "women" and "men" respectively stand for pluralization in which the status of superiority and egalitarianism is the mark of interrogation and mindset. Historically women through generations in all regions of the world represent the female personality improper, indeterminate, indifferent, formless not fixed, flows, and changes freely, connects with possessions and with physical gratification, "incapable of conscious mastery and multiple in contrast to men being unitary" (Chodrow, 1978), with self-identity, reason, objectivity, logic, and power (Ryan, 1999, p. 102). Another aspect that has been an issue of feminist discourse in the feminist literary criticism is that the female body influences, creates, and controls woman's language and writing and affects female tradition in literature (Showalter, 1977). They believe that the language in the feminists writings/novels etc., is especially as a tool of oppression (Lane, 2006, p. 71) and possible resistance to patriarchal power structures or a subversive tool for women in trying to create a space for a feminine (Ozdemir, 2003, pp. 57-79).

The language of feminist writers defines females of a particular class, culture, and historical period. It enhances women's recognition, women's consciousness i.e., it instigates unconscious feminism (Humm, 1997, p. 72) in various groups. It promotes to develop a new feminist theory to address social vision and radical political implications of female consciousness in women's groups. The language of feminism also advocates controversial liberal humanism which brings woman indeed at the centre from periphery, evolves woman as feminine and epitomizes woman's insignificance of life as the fulfillment of her own femininity that is the order and custom prevalent in patriarchy. Betty Friedan opines that woman has to step forward through her educational opportunities to save herself from being conformed to the "feminine mystique" (Friedan, 1963). 
With reference to Frieden's "feminine mystique", it is analyzed that feminists are concerned about cultural definitions of femininity which signifies sexual attractiveness, sex-role stereotyping that man assumes to dominate women, while women attempts to achieve it. In both cases, it is and it was a prescription of failure, victimization and several mental illnesses (Chesler, p. 299). In the same context, Kate Millet draws the social psychology of women who considers their anatomy is "destiny". In these references the woman is a symbol of subject as well as object, a margin and the other, a victim and a material.

The human behavior as regards perceptions and existence, identity and self-image decides a way of masculinity powerful, masterly, competent, whereas femininity vulnerable, dependent and subordinate. Julia Kristeva in this regard suggests an end to all forms of patriarchal or sexist power and demanded women's movement should take up issue of the hysteric — split between women's body and human laws, then only reconstruction can be followed up. Indeed it manifests an impasse, revolt, and unrest to dissolve this binary and to resolve the old order of submission to the male demands; besides this it problematizes the master-discourse and reframes a language that appears truly subversive. It potentially raises unsettled political discourses on feminism. Subsequently mapping the feminine existence is not the order of significance, while positioning women excessively or in transgression, Gyatri Spivak in this context states that feminism must seriously consider the material histories and lives of the Third World women in its account of women's struggles of oppression (Morton, 2003, p. 71). Gyatri Spivak has radically transformed the notion of feminist ethics and western feminism by arguing that woman should not be understood or defined or visualized as independent entity of humanist structure, instead, her position should be evaluated in terms of her subjection to women in power, hegemonic domination and to see her minority status in context of ethnicity, race, colour, and sex also. According to her, on the whole feminist thought has to counter strategic essentialism that draws women's subordination in culture and society. Secondly, she raises the challenge for western feminism how to unlearn dominant representations so that the lives of and experiences of disempowered groups can be the subject of political discourse. Thirdly, she aims to awaken self-consciousness universally to revisit to the textual scholarship of western feminist work and remembering the silent voices of subaltern women.

Michel Foucault, in the book titled History of Sexuality (Vol. I), suggests that the historical constitution of the body has been the locus of resistance and freedom. On the other hand it also implies at the same time that the normative practices by women are paradoxically experienced in terms of "power" and "control" by the women themselves (Bartky, 1990; Bordo, 1993). Secondly, according to Foucault, to historicize sex also expresses cultural construction, there is no such gender identity, but it is assumed on the basis of biological foundations. To relate gendered subjects with power and sex convey the notions according to norms, that idealize the repetitive individual behavioural pattern and oppressive power relations. Cultural construction of essential identities such as male and female gender identities or of (homosexuals) gay and lesbian identities or of heterosexual identities is targeted in context of sexual politics at the deep level, although at surface level one cannot deny the reality that these appear natural and essential. Thus, Foucault sees the body as the tool of power; the source of freedom, and resistance against power, while sexuality as a practice or a way of being that provides possibilities for being otherwise, rather than as a psychological or biological condition that we must reveal the truth about. It should be transferred from the realm of biological necessity to the realm of practices of freedom (Taylor, 2011). Judith Butler and Michel Foucault both understand that the body is performing the complex relationship between subject, power, and sex. Judith Butler in the book Gender Trouble: Feminism and Subversion of Identity questions the subversive performativity of the body and the gender expression 
regarding the trouble of gender identity. She discusses how perception and body are discursively constructed through exclusion, taboo, and abjection (Salih, 2002). In the book Bodies That Matter: On the Discursive Limits of "Sex", Butler opines that bodies have the potential for subversion, therefore performativity of the bodies need to be rethought from the point of gender lens; there should be freedom to challenge and resist both subversion and oppression that happens due to historicization of sex and sexuality on account of race, class and gender classifications, although they are in no way prior to race. Thus Spivak, Butler and Foucault bring feminist contentions in the light of post-structuralism's citations. Jacques Derrida believes that identities and bodies matter in preformativity and citationality (Sherlock, p. 4). According to Derrida language should go across social contexts and social identity of subjects in order to be meaningful in spatial and temporal contexts. Even Butler emphasizes that social category and identity of "gender" should be re-performed across situations in order to remain normative and socially meaningful (p. 4).

\section{Conclusion}

Thus, the aforesaid fictional narratives metaphorically discuss emotions of the women as metaphor to understand their struggle for bringing out their assertion in the language which they know as per their thoughts, exposure, and sentiments. These narratives justify the women's collective unconsciousness towards her self-development, her role and responsibility to humanity, society, and culture as well as the men's negligent attitude to women, work, and health; these factors subsequently set a complex structure of interaction and behaviour as per accepted social attributes, constraints, and milieu. Unless the women's consciousness integrates counter mechanisms with powerful forces of environment, surroundings, and conditions; the behavior pattern of women and men cannot be changed for oneness and equality. The women's movement should constitute the struggle for society free of exploitation, oppression and it should be identical with the aims of proletarian class struggle and feminist contentions as regards self-transformation and participation of women in the issues for women, by women, and of the women.

\section{References}

Aparajita, S. (Ed.). Fiction on Indian Subcontinent. In Modern Fiction Studies: A Searchable Index. Retrieved from https://www.cla.purdue.edu/english/mfs/vol39.htm

Bartky, S. L. (1990). Femininity and Domination: Studies in the Phenomenology of Oppression. New York: Routledge.

Bordo, S. (1993). Unbearable Weight. Berkeley, CA: University of California Press.

Boulmelha, Penny. (1982). Tomas Hardy and Women: Sexual Ideology and Narrative Form. Sussex: Harvester Press. The Review of English Studies. (1984). United Kingdom: Oxford University Press. Retrieved from http://www.jstor.org/stable/516416

Butalia, U. (2006). Inner Line: Zubaan Anthology of Short Stories by Indian Women. India: Kali Publications.

Butler, J. (1990). Gender Trouble: Feminism and Subversion of Identity. New York: Routledge.

Butler, J. (1993). Bodies that Matter: On the Discursive Limits of “Sex”. New York: Routledge.

Butler, L. St. J. (1978). Thomas Hardy. Cambridge: Cambridge University Press.

Card, C. (2003). The Cambridge Companion to Simone De Beauvoir. Cambridge: Cambridge University Press.

Chesler, Phyllis. (2005). Women and Madness. Palgrave: Macmillan.

Chodrow, N. (1978). The Reproduction of Mothering: Psychoanalysis and the Sociology of Gender. London: University of California Press Ltd.

Derrida, J. (1988). Archive Fever: A Freudian Impression. United States: University of Chicago Press.

Duffin, H. C. (1916). Thomas Hardy: A Study of the Wessex Novels. Manchester: The University Press.

Eagleton, T. (2005). The English Novel—An Introduction. USA: Blackwell Publishing.

Engel, S., et al. (2004). New Perspectives for the Liberation of Women-A Polemical Treatise. Delhi: Rainbow Publishers.

Essed, P., et al. (2005). A Companion to Gender Studies. USA: Blackwell Publishing. 
Fiedelson, C. Jr. (1953). Symbolism and American Literature. USA: University of Chicago Press. Foucault, M. (Ed.). (1986). History of Sexuality. (R. Hurtley, Trans.). New York: Vintage. Friedan, B. (1963). Feminine Mystique. USA: W.W. Norton and Co.

Grimshaw, J. (1986). Philosophy and Feminist Thinking. UK: University of Minesota Press.

Hardy, T. (2002). Tess of the Dubervilles. K. N. Khandelwal, (Ed.). Agra: Laxmi Narain Agarwal.

Hawthorne, N. (1999). The Scarlet Letter. New Delhi: Rama Brothers.

Humm, M. (1997). Feminism and Film. USA: Indiana University Press.

Irigaray, L. (1980). "When our lips speak together”. Signs, Vol. 6(1). Women: Sex and Sexuality.

Irigaray, L. (1991), Philosophy in the Feminine. UK: Routledge.

Irwin, J. (2010). Derrida and Writing of the Body. In D. Hillman et al (Eds.), The Cambridge Companion to Body in the Literature. New York: Cambridge University Press.

Kalaidjain, W. (2005, 2008). The Cambridge Companion to American Modernism. New York: Cambridge University Press.

Kristeva, J. (1975/1980). From One Identity to Another. T. Moi, (Ed.). New York and Guildford, Surrey: Columbia University Press.

Lall, R. (1981). Emma. New Delhi: Rama Brothers Publication Division.

Lane, R. J. (2006). The Postcolonial Novel. UK: Polity Press.

Lawerence, D. H. (2002). "Essay on Hawthorne and The Scarlet Letter”. In E. Greenspan, L. Vasey, and J, Worthen (Eds.), Studies in The Classified American Literature. Cambridge: Cambridge University Press.

Lyon, J. (2005/2008). The Cambridge Companion to American Modernism. Walter Kalaidjian, (Ed.). New York: Cambridge University Press.

Morton, S. (2003). Gayatri Chakravorty—Spivak. New York: Routledge Publications.

Ozdemir, E. (2003). “Recoding Narrative-Margaret Atwood's Surfacing”. The Postcolonial Novel. UK: Polity Press.

Peta, B., \& Mummery, J. (2009). Understanding feminism—difference. New Delhi: Rawat Publications.

Rose, H. (2001). Love Power and Knowledge: Towards a Feminist Transformation of the Sciences. Portugal: Portuguese Ministry of Culture Press.

Ryan, M. (1999). Literary Theory: A Practical Introduction. UK: Blackwell Publishing.

Salih, S. (2002). Judith Butler. London and New York: Routledge.

Schiek, W. J. (2009). "Excitement and consciousness in the romance tradition”. In R. P. Lamb and G. R. Thomson (Eds.), American fiction-1865-1914. UK: Blackwell Publishing.

Sherlock, S. (2014). The Performativity of Value: On the Citability of Cultural Commodities. United Kingdom: Lexington Books.

Showalter, E. (1977). A literature of their own: British women novelists from Brontë to Lessing. N.J.: Princeton University Press.

Shukla, B. A. (2008). The British feminists. Jaipur: Book Enclave.

Sunder Rajan, R. (1993). The Feminist Plot and the National Allegory: Home and World in two Indian Women's Novels in English (Vol. 39. pp. 71-92). Retrieved from https://www.cla.purdue.edu/english/mfs/vol39.htm

Taylor, D. (2011). Michel Foucault-Key Concepts. UK: Acumen Publishing Limited.

Watkins, S. (2001). Twentieth Century Women Novelists_Feminist Theory into Practice. New York: Palgrave.

Wollstonecraft, Mary. (1792). A Vindication of the Rights of Woman: With Strictures on Political and Moral Subjects. London: Source Book Press.

Zahavi, Dan. (2005). Subjectivity and Selfhood: Investigating the first-Person Perspective. USA: Massachusetts Institute of Technology. 